\title{
Seismic Response of Geocell Retaining Walls Through Shaking Table Tests
}

\author{
G. Madhavi Latha ${ }^{1}$ G. S. Manju ${ }^{1}$
}

Received: 23 December 2015/ Accepted: 18 February 2016/Published online: 5 March 2016

(c) Springer International Publishing Switzerland 2016

\begin{abstract}
Performance of geocell retaining walls under seismic shaking conditions is studied in this paper. Shaking table tests on geocell retaining walls subjected to ground shaking conditions of different accelerations and frequencies are discussed. Retaining wall models of $600 \mathrm{~mm}$ height were constructed using a sand backfill with layers of geocells stacked one above the other to form the facing. Geocells in these tests were constructed using planar geonets by stitching them into a honeycomb network. Material used for making geocells, number of geocells in each layer, slope of the facing and infill material of geocells were varied in different tests. These geocell retaining walls were subjected to 100 cycles of sinusoidal base shaking at accelerations ranging between 0.2 and $0.3 \mathrm{~g}$ and frequency range of $1-7 \mathrm{~Hz}$. Response of retaining walls was monitored in terms of acceleration amplifications and wall deformations at different elevations. It was observed that all geocell retaining walls were extremely strong to seismic shaking. Acceleration amplifications and displacements increased with increase in base acceleration or shaking frequency. It was observed that the detrimental effect of increasing ground motion parameters on the wall response was more significant than the beneficial effect of improvement in geocell parameters.
\end{abstract}

Keywords Geocell - Retaining wall - Seismic response · Model tests $\cdot$ Shaking table $\cdot$ Soil reinforcement

G. Madhavi Latha

galimadhavi@gmail.com; madhavi@civil.iisc.ernet.in

G. S. Manju

manjugs@civil.iisc.ernet.in

1 Indian Institute of Science, Bangalore, India

\section{Introduction}

It is about a half century since the construction of first mechanically stabilized earth wall and three decades since the construction of first geosynthetic reinforced soil (GRS) wall. By now the concept of reinforced earth wall is established as a versatile earth retention technique. The advantages of GRS walls including the savings in cost, ease of construction, better performance under seismic loads, design flexibility, capacity to sustain large deformations without structural distress and aesthetics made them suitable for a variety of civil engineering applications. GRS walls combined with a fascia of geocells can create highstrength retention systems because geocells as fascia offer strong and durable wall face protection. Geocells are three dimensional cellular network of polymeric material, which can be filled with sand, aggregate or several other choices of infill materials, for the use in construction of retaining walls, slopes and embankments. The all-round confinement effect of geocells combined with the efficient load transfer between interconnected cells make them structurally strong and their flexible wall structures allows them to conform to the complex geometries of various reinforced soil structures. The beneficial effects of geocells in various engineering applications were investigated by several earlier researchers [1-11]. Also geocells on wall face facilitate the growth of vegetation, offering additional advantage of bioreinforcement, making it an engineered green solution which is sustainable.

Use of geocells specifically in retaining walls and their performance was studied by very few researchers. Bathurst and Crowe [12] discussed the design and construction of earliest flexible gravity retaining walls in North America using geocells. Racana et al. [13] studied the mechanical response and failure mechanisms of two reduced scale 
geocell retaining wall models constructed with soft and rigid geocell materials. Rigid wall was constructed using paper geocells and soft wall was constructed using polyan cells, whose elastic modulus was 30 times less than that of the paper. These tests revealed that the failure in geocell retaining walls occurs by the formation of an active block with no passive anchorage movement. The failure mechanism was not altered by the change in geocell material, however rigid walls showed comparatively lesser displacements because of the higher elastic modulus of the geocells.

Chen and Chiu [14] carried out laboratory model tests on geocell retaining walls to study the effects of wall height, inclination of the facing, loading area and position of the embedded reinforcement. Results from these tests showed that the deformation on the wall face and backfill settlement both increased with increasing facing angle and surcharge. Reinforced models showed comparatively lesser deformations. Based on these model tests, guidelines for the design and construction of geocell retaining walls were developed. Later Chen et al. [15] presented the numerical analysis of these model experiments. Gomez [16] performed centrifuge tests at $20 \mathrm{~g}$ on geocell retaining wall models under fully and partially saturated conditions. It was observed that retaining wall models in partially saturated condition could carry $27 \%$ more surcharge than saturated wall models because of the suction generated in unsaturated soils. Soude et al. [17] presented the effect of localized horizontal impact on geocell retaining walls by carrying out model tests on one-tenth scale geocell walls. Model walls of $60 \mathrm{~cm}$ height ( $6 \mathrm{~m}$ prototype) were subjected to impact of vehicle running at a speed of $10 \mathrm{~m} / \mathrm{s}$, simulating a speed of $110 \mathrm{~km} / \mathrm{h}$ in full-scale and numerical analysis of these impact load tests were presented.

Seismic response of geosynthetic reinforced soil walls is well documented in literature [18-29]. Research on seismic response of geocell retaining walls is very limited. Leshchinsky et al. [30] and Ling et al. [31] presented the results of shaking table tests on five large-scale models of geocell retaining walls, each $2.8 \mathrm{~m}$ high, constructed with different geocell and geogrid combinations and subjected seismic shaking corresponding to Kobe earthquake of 1995. All these model walls performed satisfactorily under the simulated earthquake motions. Failure surfaces developed in the model tests were analyzed and equivalent seismic coefficients for reinforced geocell walls were estimated. However, prototype geocells having tensile strength of $50 \mathrm{kN} / \mathrm{m}$ were used in the model experiments presented in these studies. Strength of reinforcement was not scaled down along with the dimensions of the retaining walls in model experiments. Also, similitude laws to correlate the results from model experiments to field retaining wall cases were not discussed, making it difficult to extrapolate the results to field cases.

Systematic studies on the seismic response of geocell retaining walls, especially to study their acceleration and displacement response affected by various levels of ground motion parameters are not available in literature. To investigate these aspects, shaking table tests are carried out in the present study and the results are discussed to analyze the response of geocell walls with different geocell configurations under the influence of sinusoidal ground shaking conditions of different accelerations and frequencies. Tensile strength of geocell material is scaled down in the present study to suit the similitude requirements of the model tests, keeping in view of the range of tensile strength of geocells typically used in field.

\section{Materials Used For Testing}

\section{Sand and Gravel}

Sand was used as backfill in the retaining walls and also to fill the rear geocells in few shaking table tests. Sand used in this study is poorly graded, classified as SP according to unified soil classification system. Gravel was used to fill front geocells in the model tests. Average size of the gravel was $12 \mathrm{~mm}$ and according to unified soil classification system, it was classified as poorly graded gravel (GP). Properties of the sand and gravel used in the study are presented in Table 1. Grain size distributions of these materials are shown in Fig. 1.

\section{Geocells}

Geocells were fabricated from polypropylene geonet available in market. All geocells were of $100 \mathrm{~mm}$ pocketsize and $100 \mathrm{~mm}$ height fabricated into a network of honeycomb shaped cells. Geocells cells were manually connected using polyethylene wire having tensile strength less than that of the geonet. Load-elongation responses of

Table 1 Properties of fine sand and Gravel used

\begin{tabular}{lll}
\hline Property & Fine sand & Gravel \\
\hline Effective grain size $\left(D_{10}\right)(\mathrm{mm})$ & 0.065 & 5.5 \\
Coefficient of uniformity $\left(C_{\mathrm{u}}\right)$ & 4.46 & 1.82 \\
Coefficient of curvature $\left(C_{\mathrm{c}}\right)$ & 1.36 & 0.89 \\
Soil Classification & $\mathrm{SP}$ & $\mathrm{GP}$ \\
Minimum unit weight $\left(\mathrm{kN} / \mathrm{m}^{3}\right)$ & 14.57 & 18.4 \\
Maximum unit weight $\left(\mathrm{kN} / \mathrm{m}^{3}\right)$ & 17.91 & 21.5 \\
Friction angle (Degrees) from direct shear test & 40 & 49 \\
\hline
\end{tabular}




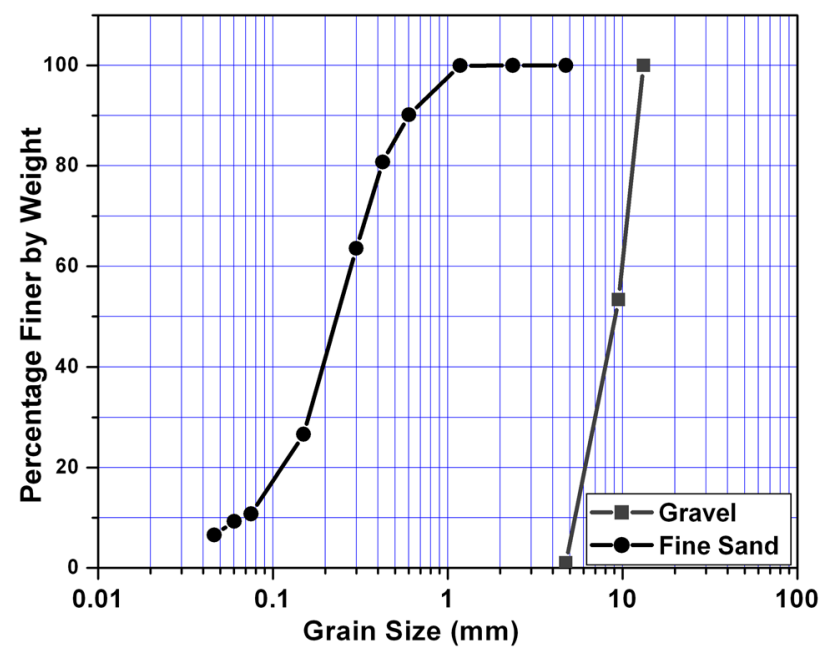

Fig. 1 Grain size distribution of fine sand and gravel used

geonet and the joint are presented in Fig. 2. From this figure, it is observed that the joint strength of the geocells is about $70 \%$ of the material strength, comparable to the ultrasonically welded geocells used in field. Properties of the geonet are given in Table 2. Geocells were connected to an additional layer of basal geonet provided underneath using thin steel wires to maintain their shape and size.

\section{Similitude Laws}

For the model geocell retaining walls tested in the present study, the size of the model is determined based on the dimensions of the shaking table facility available. Also, shaking table tests are $1 \mathrm{~g}$ model tests carried out on reduced scale models. The stress levels in the experiments

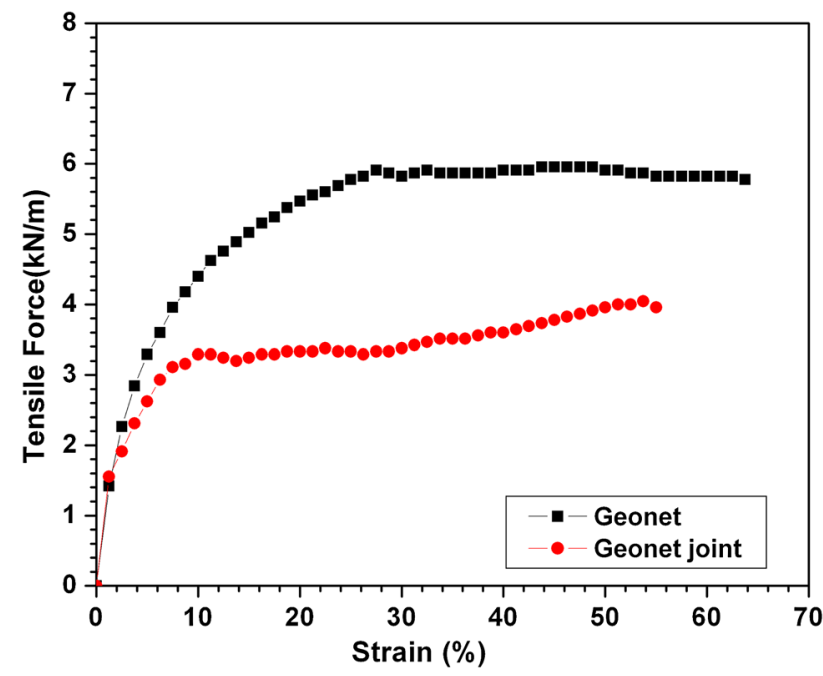

Fig. 2 Load -elongation response of the geonet and the joint
Table 2 Properties of the Geonet

\begin{tabular}{ll}
\hline Property & Value \\
\hline Mass per unit area $\left(\mathrm{g} / \mathrm{m}^{2}\right)$ & 750 \\
Nominal thickness $(\mathrm{mm})$ & 1.5 \\
Aperture size $\left(\mathrm{mm}^{2}\right)$ & $7 \times 8$ \\
Ultimate tensile strength $(\mathrm{kN} / \mathrm{m})$ & 5.96 \\
Yield point strain $(\%)$ & 48.75 \\
Secant modulus of Geonet at 1\% strain $(\mathrm{kN} / \mathrm{m})$ & 100 \\
Secant modulus of Geonet at 2\% strain $(\mathrm{kN} / \mathrm{m})$ & 62 \\
Geocell joint strength $(\mathrm{kN} / \mathrm{m})$ & 4.04 \\
\hline
\end{tabular}

do not truly represent the stresses in field because of the gravity effects and boundary effects in model studies. In order to make use of the results obtained from model tests to the respective full size prototype, scaling laws are used. Iai [32] presented similitude laws for the $1 \mathrm{~g}$ model tests from basic definitions of effective stress, strain and constitutive law, overall equilibrium and mass balance. A geometric scale factor, $\lambda_{\mathrm{M}}$, was defined as the proportionality constant between the model and prototype geometry. These similitude laws were later verified by several researchers for studies related to seismic behaviour of soil structures [14, 33-35]. For the present study, the geometric scale factor, $\lambda_{\mathrm{M}}$, is taken as 10 . Accordingly, the height of the model retaining wall was kept as $0.6 \mathrm{~m}$, corresponding to $6 \mathrm{~m}$ in field. The scaling factors computed for relating various physical quantities in models to those in prototype are given in Table 3. Typical range of field values of these parameters obtained from several case studies reported in literature are also presented in Table 3. All linear dimensions are scaled down by a factor 10 in the model and hence the dimensions of geocells and aperture sizes of geonet for the prototype wall should be taken as 10 times the model values. Exact scaling of sand and gravel grains is impossible. Fine sand used in the model tests has a mean particle size $\left(D_{50}\right)$ of $0.23 \mathrm{~mm}$, representing coarse sand of $2 \mathrm{~mm}$ mean particle size in field. Gravel. Similarly, the mean particle size of gravel in model tests is $9 \mathrm{~mm}$, representing coarse gravel-cobble in field.

\section{Shaking Table Tests}

A uniaxial shaking table with a pay load capacity of 1 ton and table size of $1 \mathrm{~m} \times 1 \mathrm{~m}$ is used in this study. All tests were carried out inside a laminar box to minimize the boundary effects. A rectangular laminar box with inner dimensions of $500 \mathrm{~mm} \times 1000 \mathrm{~mm}$ and $800 \mathrm{~mm}$ (Length $\times$ Width $\times$ Depth) fabricated using fifteen rectangular hollow aluminium layers separated by linear roller 
Table 3 Scaling factors based on similitude laws

\begin{tabular}{|c|c|c|c|c|c|}
\hline Parameter & $\begin{array}{l}\text { Model } \\
\text { parameter }\end{array}$ & $\begin{array}{l}\text { Equation for scaling } \\
\text { factor }=(\text { Prototype/Model })\end{array}$ & $\begin{array}{l}\text { Scaling } \\
\text { factor }\end{array}$ & $\begin{array}{l}\text { Prototype } \\
\text { parameter }\end{array}$ & $\begin{array}{l}\text { Typical range } \\
\text { of field values }\end{array}$ \\
\hline Acceleration $(\mathrm{g})$ & $0.2,0.3$ & 1 & 1 & $0.2,0.3$ & $0.05-3$ \\
\hline Height of the retaining wall (m) & 0.6 & $\lambda_{\mathrm{M}}$ & 10 & 6 & $3-15$ \\
\hline Base width of geocell layer (m) & $0.2,0.4$ & $\lambda_{\mathrm{M}}$ & 10 & 2,4 & $0.8-5$ \\
\hline Unit weight of Soil $\left(\mathrm{kN} / \mathrm{m}^{3}\right)$ & 17.13 & 1 & 1 & 17.13 & $16-20$ \\
\hline Frequency $f_{m}(\mathrm{~Hz})$ & $1-7$ & $1 /\left(\lambda_{M}\right)^{3 / 4}$ & 0.178 & $0.178-1.24$ & $0.3-10$ \\
\hline Stress & $\sigma_{m}$ & $\lambda_{\mathrm{M}}$ & 10 & $10 \times \sigma_{m}$ & $\mathrm{NA}^{\mathrm{a}}$ \\
\hline Time & $\mathrm{t}_{m}$ & $\lambda_{\mathrm{M}}^{3 / 4}$ & 5.62 & $5.62 \times \mathrm{t}_{m}$ & $\mathrm{NA}^{\mathrm{a}}$ \\
\hline Ultimate tensile strength of geocell material $(\mathrm{kN} / \mathrm{m})$ & 5.96 & $\lambda_{\mathrm{M}}$ & 10 & 59.6 & $20-300$ \\
\hline
\end{tabular}

${ }^{a}$ Not Applicable (NA) because it is specific to a location or a moment

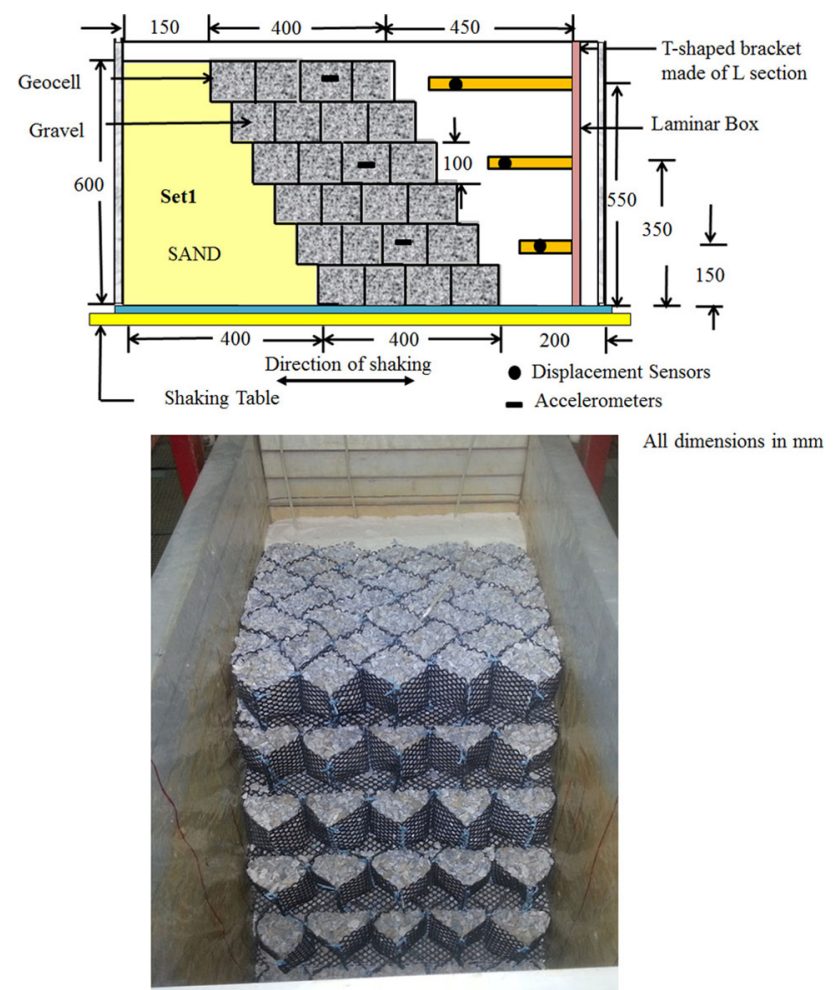

Fig. 3 Schematic diagram and photograph of the model retaining wall with instrumentation for Set1

bearings to facilitate frictionless independent movement of layers was used to build the model retaining walls. Further, a polyethylene sheet was used to cover the inside of the laminar box to cover the gap between the rectangular panels and also to minimize the friction between the model and the laminar box. Height of the model retaining walls was $600 \mathrm{~mm}$ in all tests and the footprint was $800 \mathrm{~mm} \times 500 \mathrm{~mm}$ (Length $\times$ Width). Three different sets of model tests were carried out in this study, named as Set1, Set2 and Set3, with variation in geocell configuration

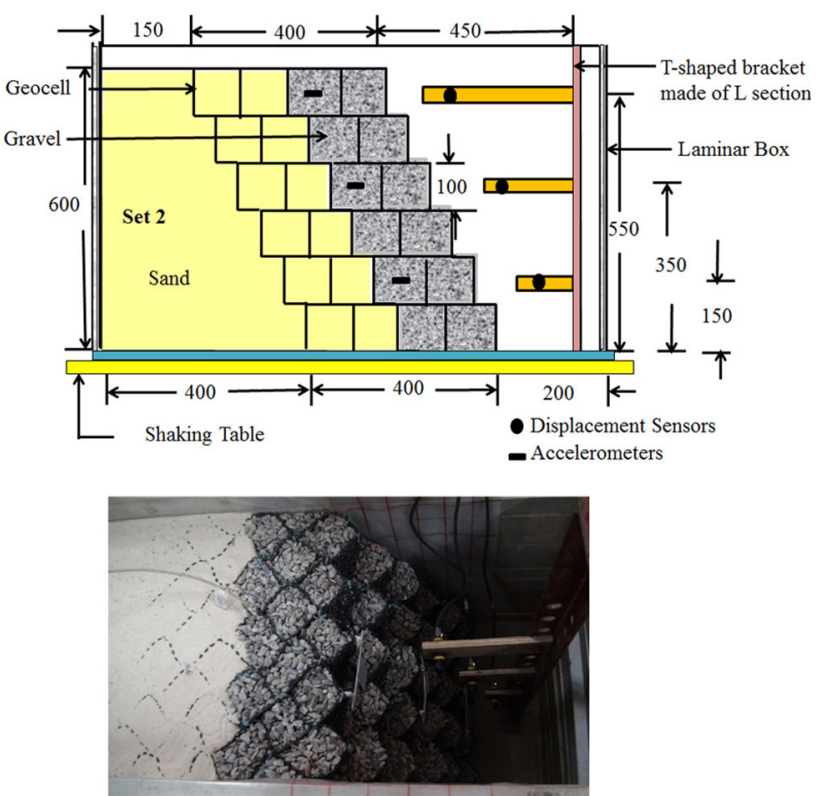

Fig. 4 Schematic diagram and photograph of the model retaining wall with instrumentation for Set 2

and infill material. In the first set of experiments Set1, facing of the retaining wall comprised of 4 geocells along the length of the wall, all filled with gravel. In the second set of experiments Set2, facing comprised of four geocells along the length of the wall, gravel filled in two cells at the front and backfill sand filled in subsequent two cells. In the third set of experiments Set3, only two geocells were placed at the facing, all cells filled with gravel. Figures 3, 4 and 5 present the schematic diagrams of model tests in sets Set 1 , Set 2 and Set 3 respectively. There were five geocells completing the width of $500 \mathrm{~mm}$ of all model walls. Acceleration amplitude of shaking was varied as 0.2 and $0.3 \mathrm{~g}$, keeping the frequency as $1,2,3$ and $7 \mathrm{~Hz}$ in different sets of experiments. Total 24 model shaking table tests 

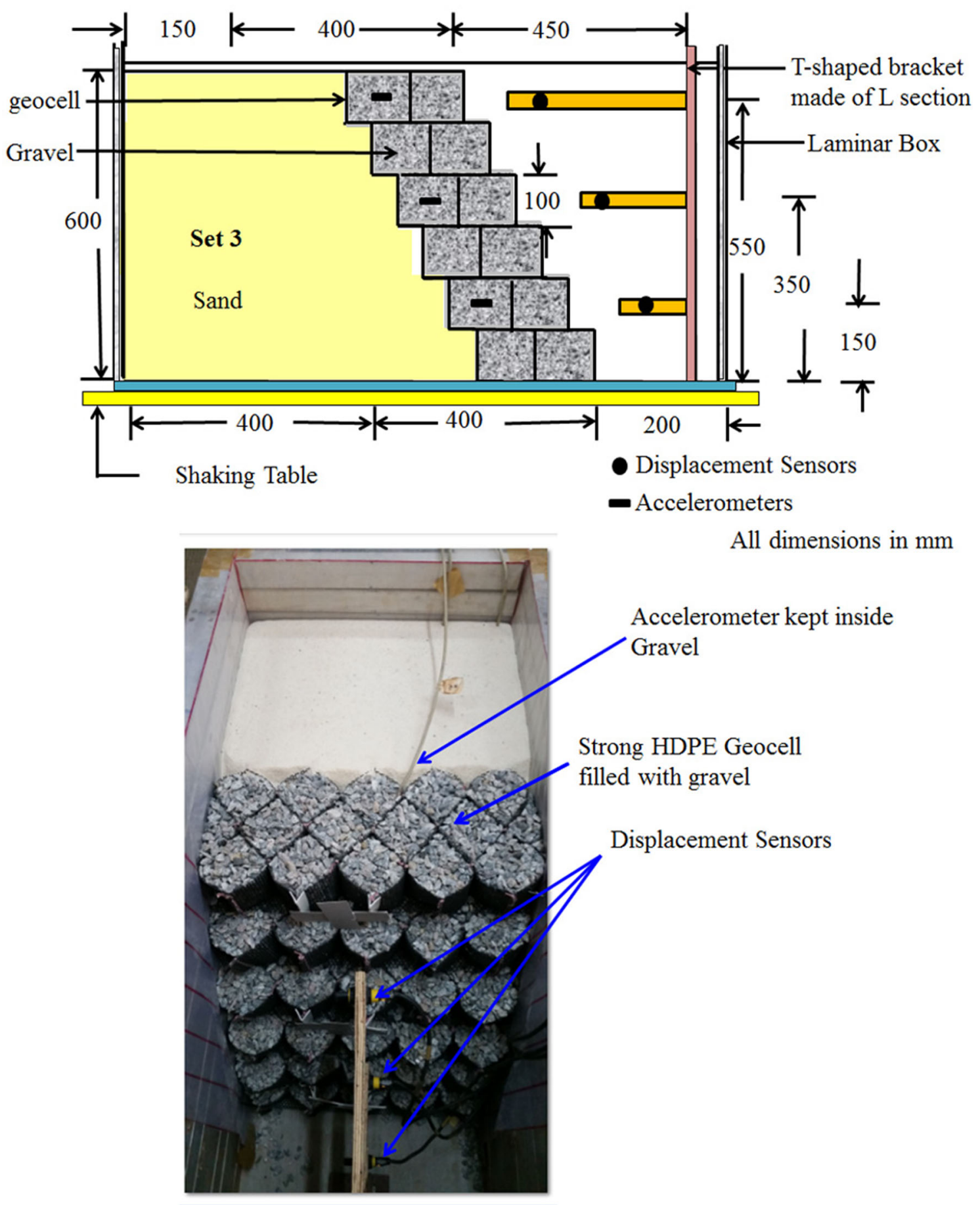

All dimensions in $\mathrm{mm}$

Accelerometer kept inside Gravel

Strong HDPE Geocell

filled with gravel

Displacement Sensors

Fig. 5 Schematic diagram and photograph of the model retaining wall with instrumentation for Set 3

were carried out in this study. Table 4 gives the test matrix showing different tests, parameters varied and the test code.

All model walls were constructed in six lifts, each of $100 \mathrm{~mm}$ height. For the construction of each lift, initially the geocell layer was placed at the facing and filled with the choice of infill material, gravel or sand according to the test set. Sand and gravel inside the cells was compacted using a steel rod to achieve uniform unit weight. Unit weight of gravel infill was $20.4 \mathrm{kN} / \mathrm{m}^{3}$ and sand infill was $17.13 \mathrm{kN} / \mathrm{m}^{3}$. Once the geocells were filled, backfill sand was poured behind the geocells using sand pluviation technique, to achieve a uniform unit weight of $80 \%$. Care was taken that each layer of sand was compacted 
thoroughly so that it is flush with the geocell height of that particular layer. For the construction of next lift, the next layer of geocells was laid on the top of the first layer, leaving an offset of $50 \mathrm{~mm}$ from the geocell facing of the previous layer, resulting in an overall batter of $67.4^{\circ}$. Because of this batter, length of the walls reduced in each layer, resulting in a length of $550 \mathrm{~mm}$ at the top. During the process of construction of the model retaining walls, three accelerometers, A1, A2 and A3 were embedded in gravel at the mid-height of the second geocell from the facing, at elevations 150,350 and $550 \mathrm{~mm}$ respectively from the base of the wall. Another accelerometer, A0, was fixed to the base of the shaking table to measure the base acceleration. Three displacement transducers, D1, D2 and D3, were positioned along the facing of the wall at elevations 150 , 350 and $550 \mathrm{~mm}$ respectively from the base of the wall to measure the horizontal displacements of the wall. The crest settlements were also measured after each test. Schematic diagrams showing the model retaining walls and corresponding photographs of the model retaining walls in Set1, Set 2 and Set 3 with instrumentation are shown in Figs. 3, 4 and 5 respectively.

Table 4 Shaking table model test matrix

\begin{tabular}{|c|c|c|c|}
\hline Test set & Test code & Acceleration (g) & Frequency $(\mathrm{Hz})$ \\
\hline Set1 & S1A3F1 & 0.3 & 1 \\
\hline Set 1 & $\mathrm{~S} 1 \mathrm{~A} 3 \mathrm{~F} 2$ & 0.3 & 2 \\
\hline Set1 & S1A3F3 & 0.3 & 3 \\
\hline Set1 & S1A3F7 & 0.3 & 7 \\
\hline Set1 & $\mathrm{S} 1 \mathrm{~A} 2 \mathrm{~F} 1$ & 0.2 & 1 \\
\hline Set1 & $\mathrm{S} 1 \mathrm{~A} 2 \mathrm{~F} 2$ & 0.2 & 2 \\
\hline Set1 & $\mathrm{S} 1 \mathrm{~A} 2 \mathrm{~F} 3$ & 0.2 & 3 \\
\hline Set1 & S1A2F7 & 0.2 & 7 \\
\hline Set2 & $\mathrm{S} 2 \mathrm{~A} 3 \mathrm{~F} 1$ & 0.3 & 1 \\
\hline Set2 & $\mathrm{S} 2 \mathrm{~A} 3 \mathrm{~F} 2$ & 0.3 & 2 \\
\hline Set2 & S2A3F3 & 0.3 & 3 \\
\hline Set2 & S2A3F7 & 0.3 & 7 \\
\hline Set2 & $\mathrm{S} 2 \mathrm{~A} 2 \mathrm{~F} 1$ & 0.2 & 1 \\
\hline Set2 & $\mathrm{S} 2 \mathrm{~A} 2 \mathrm{~F} 2$ & 0.2 & 2 \\
\hline Set2 & $\mathrm{S} 2 \mathrm{~A} 2 \mathrm{~F} 3$ & 0.2 & 3 \\
\hline Set2 & S2A2F7 & 0.2 & 7 \\
\hline Set3 & S3A3F1 & 0.3 & 1 \\
\hline Set3 & S3A3F2 & 0.3 & 2 \\
\hline Set3 & S3A3F3 & 0.3 & 3 \\
\hline Set3 & S3A3F7 & 0.3 & 7 \\
\hline Set3 & $\mathrm{S} 3 \mathrm{~A} 2 \mathrm{~F} 1$ & 0.2 & 1 \\
\hline Set3 & $\mathrm{S} 3 \mathrm{~A} 2 \mathrm{~F} 2$ & 0.2 & 2 \\
\hline Set3 & $\mathrm{S} 3 \mathrm{~A} 2 \mathrm{~F} 3$ & 0.2 & 3 \\
\hline Set3 & S3A2F7 & 0.2 & 7 \\
\hline
\end{tabular}

Once the model was constructed, it was subjected to a sinusoidal base shaking of acceleration and amplitude corresponding to the test as per Table 4. All models were tested up to 100 cycles of base shaking. Displacements of the facing was measured through displacement sensors D1, D2 and D3 during shaking. Accelerations at different elevations were measured using accelerometers A1, A2 and A3. The accelerometers and ultrasonic displacement sensors were able to take 101 readings for every second.

To simplify the presentation of acceleration response of the wall, root mean square acceleration (RMSA) amplification factors are used to represent the acceleration response of the walls. RMSA amplification factor is the ratio of response acceleration value in the soil to that of corresponding value of the base motion. These factors are calculated using the root mean square method applied to the acceleration-time history for each accelerometer. RMSA at every elevation is calculated as per the following equation given by Kramer [36].

$\operatorname{RMSA}=\left[\frac{1}{t_{d}} \int_{0}^{t_{d}} a(t)^{2} \mathrm{~d} t\right]^{\frac{1}{2}}$

where $a(t)$ is the acceleration time history, $T_{d}$ is the duration of the acceleration record and $\mathrm{d} t$ is time interval of the acceleration record. To obtain the RMSA amplification factor, RMSA values measured at different elevations are divided by the base acceleration value for every test.

\section{Results and Discussions}

\section{Effect of Ground Motion Parameters}

Effect of acceleration and frequency of shaking on the displacements and acceleration amplifications of geocell retaining walls is studied through series of tests on geocell walls of Set1 configuration. Effect of frequency was studied by subjecting walls to a horizontal shaking at acceleration amplitudes of 0.2 and $0.3 \mathrm{~g}$ and frequencies $1,2,3$ and $7 \mathrm{~Hz}$. Results from this set of model tests are presented in Fig. 6. Variation of wall deformations at different normalized elevations with different frequencies are shown in this figure. Figure $6 a$ presents the response at $0.2 \mathrm{~g}$ acceleration and Fig. $6 \mathrm{~b}$ presents the response at $0.3 \mathrm{~g}$ acceleration. When the retaining walls are subjected to horizontal seismic shaking, they tend to slide or overturn. Since the thickness of facing in this case is sufficient to overcome the sliding movement at the base, deformations are seen only in terms of wall movement frontward. Since the facing in these walls is layered and the layers are not connected, deformations are not cumulative. However, overall forward 
movement of the backfill and the active thrust of the backfill on the geocell facing cause the wall to deform more at higher elevations. In general, measured deformations are much smaller, considering the high acceleration amplitude of $0.3 \mathrm{~g}$ used in the tests. Higher base width and thickness of the facing in case of Set1 configuration was responsible for the lesser deformations. As observed from these plots, wall deformations increased with increase in shaking frequency for both the acceleration amplitudes. Measured maximum horizontal deformation of the wall was $2 \mathrm{~mm}$ at $1 \mathrm{~Hz}$ frequency and it increased to $4.8 \mathrm{~mm}$ at $7 \mathrm{~Hz}$ frequency when the acceleration amplitude was $0.2 \mathrm{~g}$. Similarly, maximum deformation of the wall was $3.8 \mathrm{~mm}$ at $1 \mathrm{~Hz}$ frequency and it increased to $5.6 \mathrm{~mm}$ at $7 \mathrm{~Hz}$ frequency when the acceleration amplitude was $0.3 \mathrm{~g}$. The increase in maximum deformation with increase in frequency from 1 to $7 \mathrm{~Hz}$ was about $140 \%$ in case of $0.2 \mathrm{~g}$ acceleration and it was $47 \%$ in case of $0.3 \mathrm{~g}$ acceleration. This indicates that the effect of frequency is more pronounced when the acceleration amplitude is less.

Variation of RMSA amplification factors with normalized elevation at different frequencies with acceleration amplitudes 0.2 and $0.3 \mathrm{~g}$ are plotted in Fig. $7 \mathrm{a}, \mathrm{b}$ respectively. At lower frequencies of 1 and $2 \mathrm{~Hz}$, acceleration amplifications are negligible at both the accelerations tested. Effect of frequency can be seen in terms of increase in
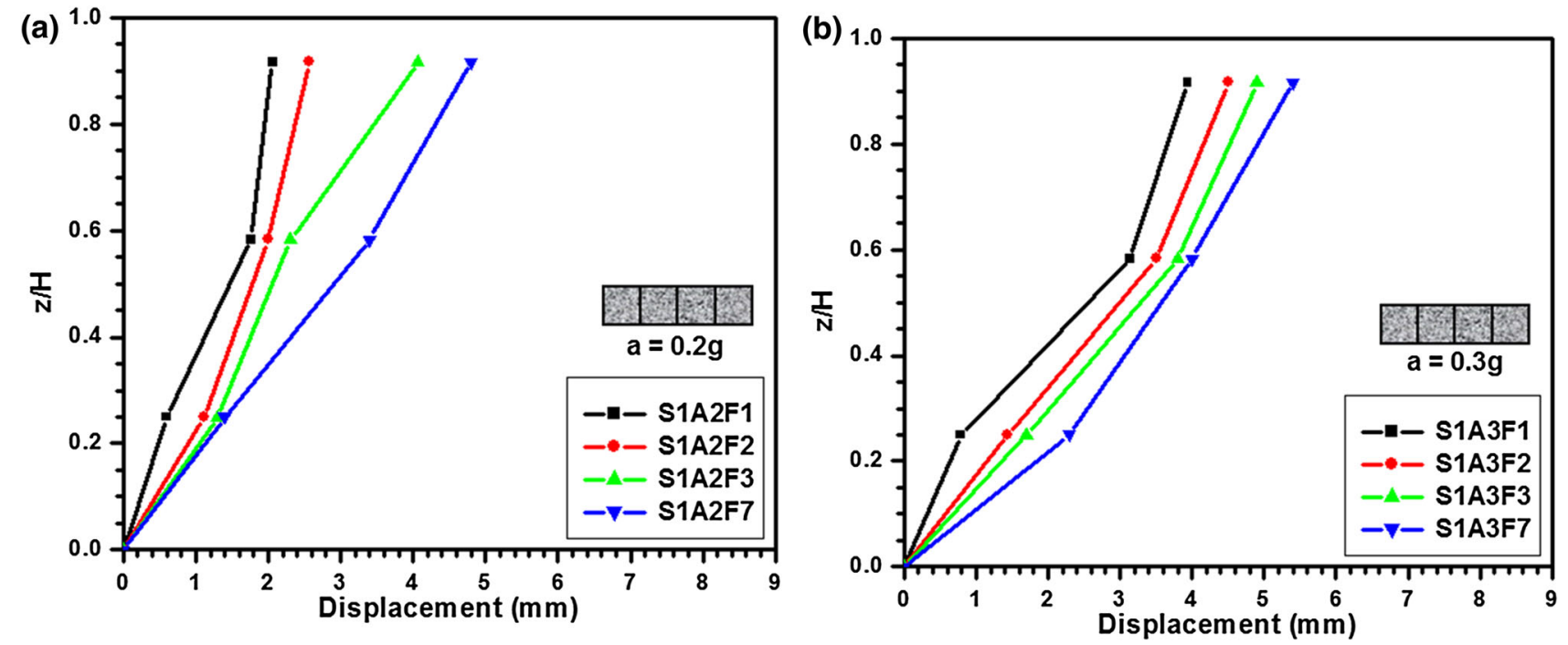

Fig. 6 Effect of frequency on wall deformations for Set1 configuration (a) $a=0.2 \mathrm{~g}$ (b) $\mathrm{a}=0.3 \mathrm{~g}$
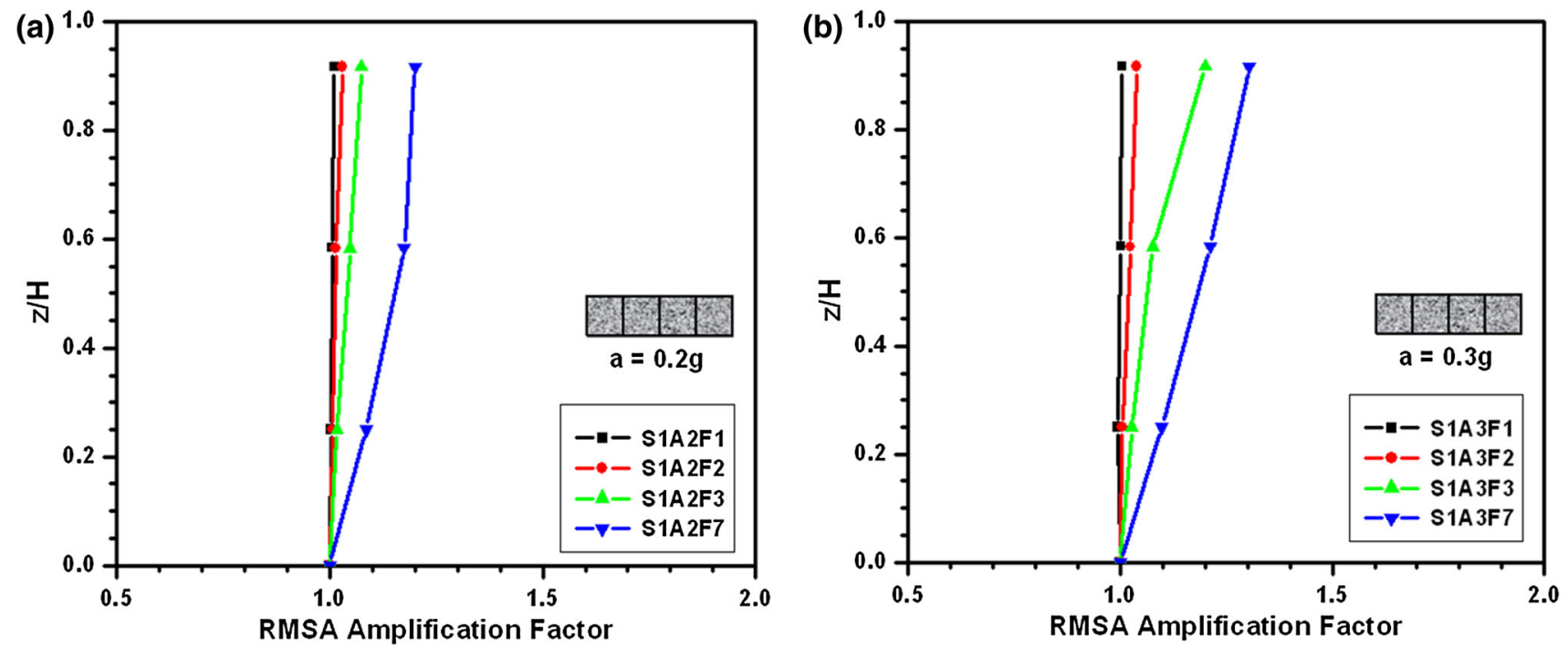

Fig. 7 Effect of frequency on RMSA amplification factors for Set 1 configuration $\mathbf{a}$ a $=0.2 \mathrm{~g} \mathbf{b}$ a $=0.3 \mathrm{~g}$ 

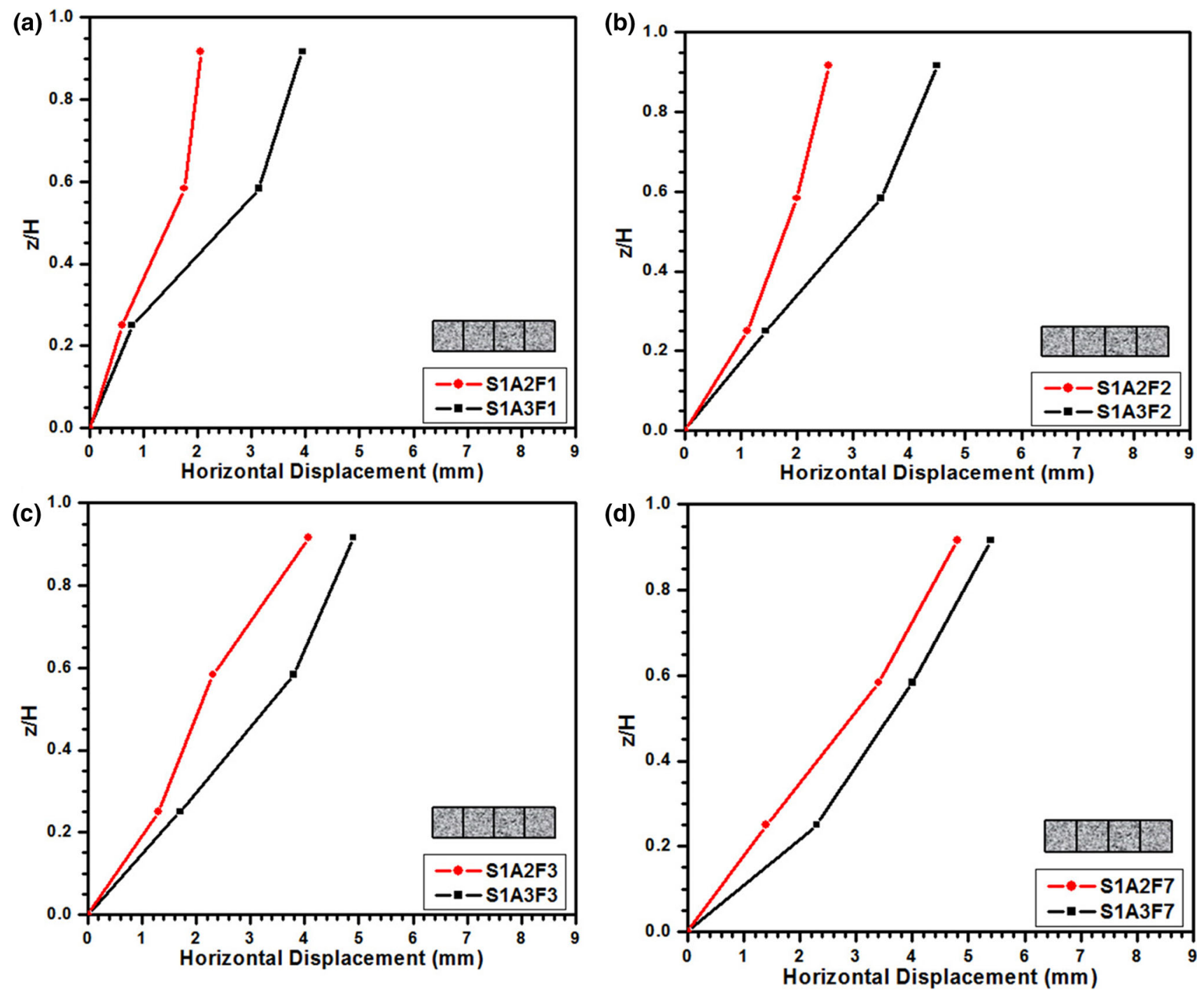

Fig. 8 Effect of acceleration on wall deformations for Set1 configuration a1 $\mathrm{Hz}$ b $2 \mathrm{~Hz}$ c $3 \mathrm{~Hz}$ d $7 \mathrm{~Hz}$

RMSA amplification factors, the effect more clear at higher elevations of the wall. In case of walls subjected to different frequencies of base shaking at $0.2 \mathrm{~g}$ acceleration, amplifications were not considerable up to a frequency of $3 \mathrm{~Hz}$, showing RMSA amplification factor close to 1.0 at all elevations and when the frequency was increased to $7 \mathrm{~Hz}$, RMSA amplification factor increased to about 1.2. In general, acceleration amplification factors varied between 1 and 1.5 for the model tests. El-Emam and Bathurst [37] suggested that below the estimated critical acceleration value, the outward acceleration amplification of the model walls will be very small, with amplification factors lying between 1.0 and 1.5, but increases significantly once the critical acceleration is exceeded. This is related to an increased loss in soil stiffness beyond the critical acceleration due to permanent deformation of the wall. Hence it is understood that the accelerations used in the present study are below the critical acceleration value for the models. When the effect of frequency is analysed at acceleration amplitude of $0.3 \mathrm{~g}$, the effect of frequency was visible from a frequency value of $3 \mathrm{~Hz}$, RMSA amplification factors being close to 1.0 at frequencies less than $3 \mathrm{~Hz}$ and the maximum RMSA amplification factor calculated for $7 \mathrm{~Hz}$ frequency was about 1.4. Unlike wall deformations, acceleration amplifications were affected by the frequencies more when the shaking acceleration was more.

Model studies to understand the effect of frequency clearly showed that the deformations and acceleration 

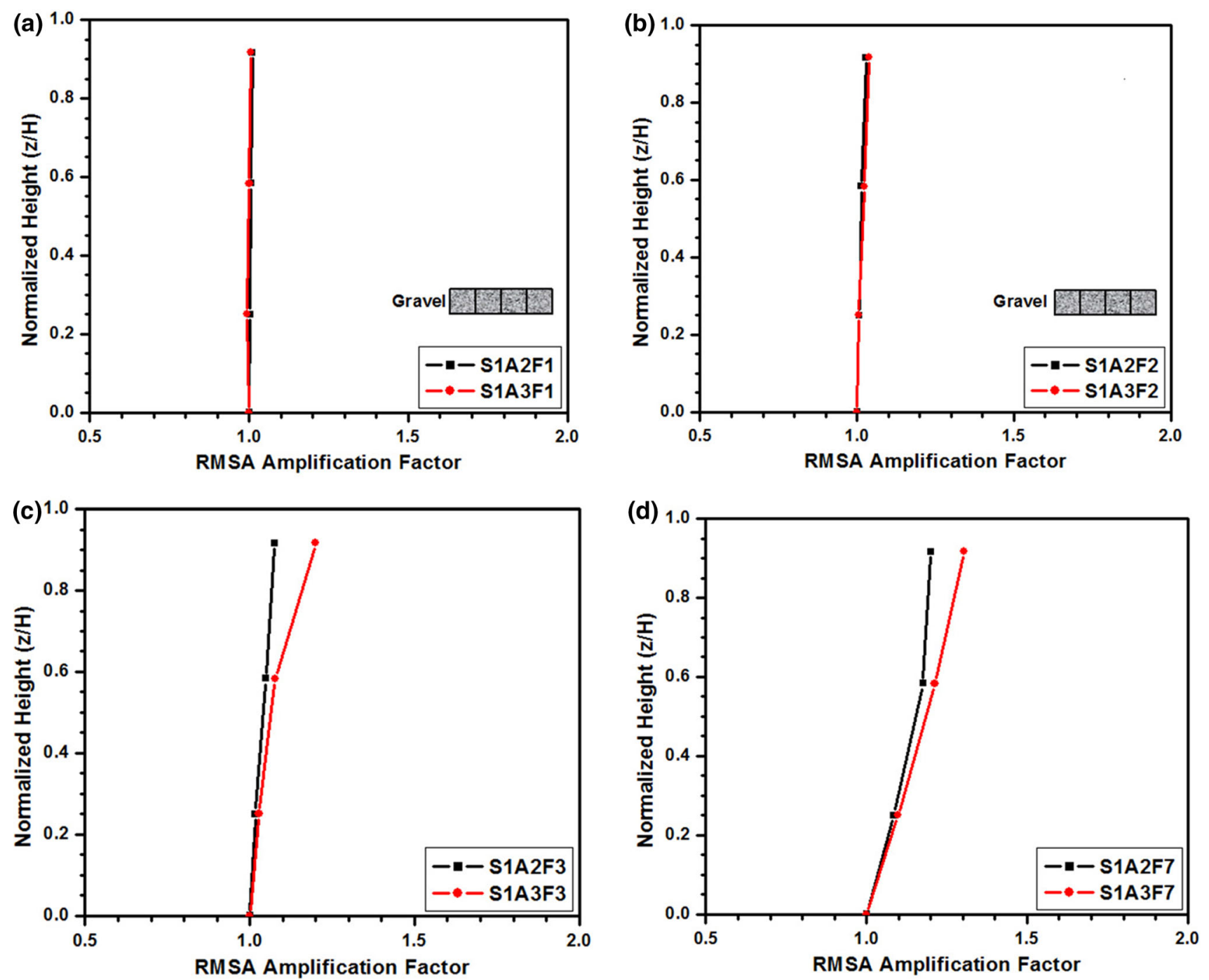

Fig. 9 Effect of acceleration on RMSA amplification factors for Set 1 configuration a $1 \mathrm{~Hz}$ b $2 \mathrm{~Hz}$ c $3 \mathrm{~Hz}$ d $7 \mathrm{~Hz}$

amplifications at different elevations of the geocell walls increased with the increase in shaking frequency, all other parameters being the same. By applying similitude laws, these results can be extrapolated to the field conditions. A $6 \mathrm{~m}$ high geocell wall of Set1 configuration will approximately displace by $56 \mathrm{~mm}$ when it is subjected to seismic shaking represented by a sinusoidal wave of frequency $7 \mathrm{~Hz}$ and acceleration amplitude of $0.3 \mathrm{~g}$. It also should be kept in mind that the model size is limited in the study and the boundary effects and scale effects still persist to certain level, even with the use of laminar box and scaling laws. Based on these interpretations and permissible deformations of the wall for serviceability, seismic design of walls can be verified.
Figure 8 shows the effect of acceleration amplitude on the seismic response of geocell retaining walls at different frequencies. In these set of model tests with Set1 configuration, two different acceleration amplitudes, 0.2 and $0.3 \mathrm{~g}$ are used. Results showed that the deformations of the wall increased with increase in shaking acceleration. As the cyclic shear stress from the shaking is directly proportional to the acceleration amplitude, walls experienced larger deformations at higher acceleration amplitudes at all frequency levels. At higher frequency of $7 \mathrm{~Hz}$, the difference in the performance with change in acceleration amplitude is not substantial because the effect of frequency has dominated the performance and the wall deformations. When RMSA amplifications are compared, slightly higher 

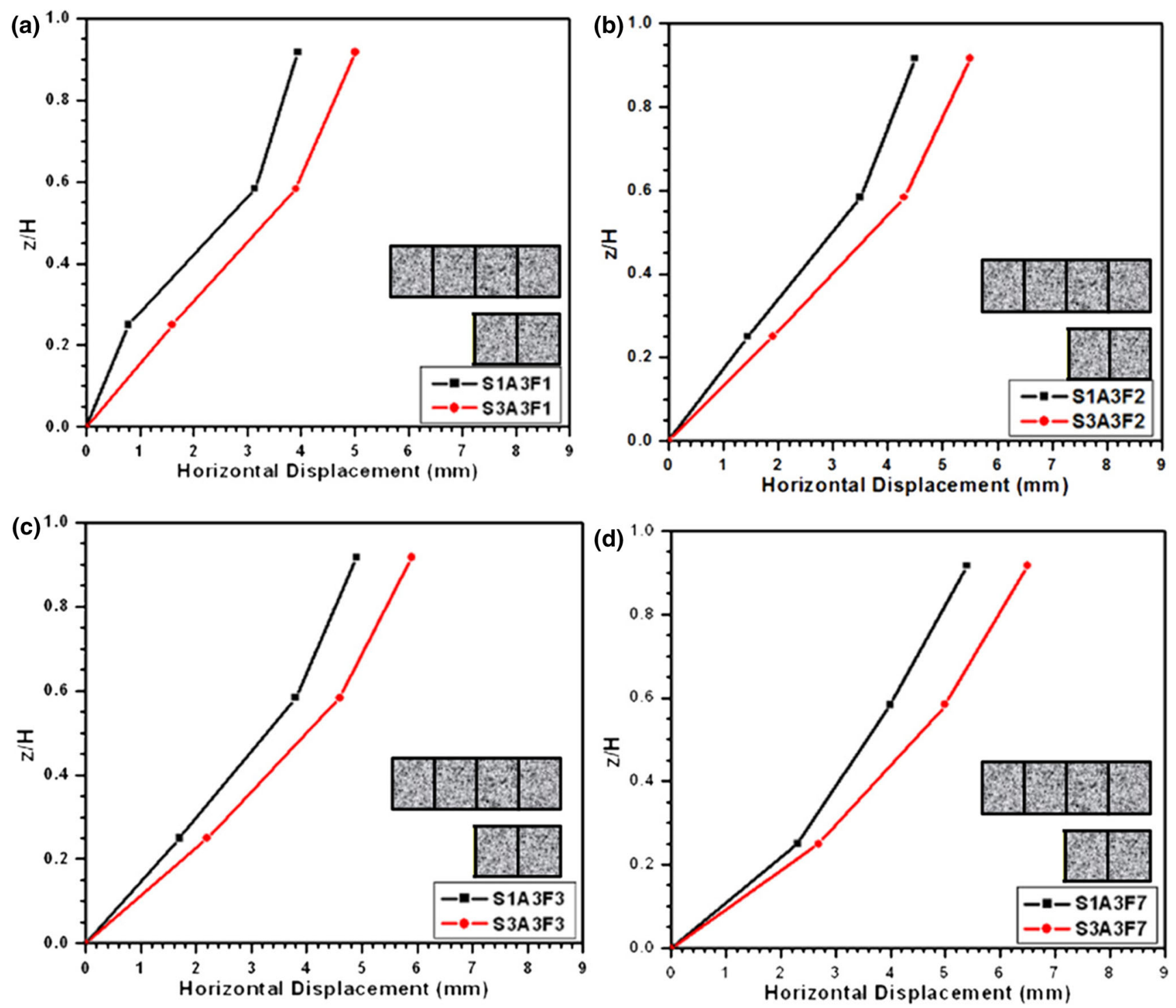

Fig. 10 Effect of geocell configuration on wall deformations a $1 \mathrm{~Hz}$ b $2 \mathrm{~Hz}$ c $3 \mathrm{~Hz}$ d $7 \mathrm{~Hz}$

amplifications were observed at higher elevations with higher acceleration amplitudes, as shown in Fig. 9. At lower elevations, the acceleration amplifications were not affected by change in acceleration amplitude. These results are in agreement with the results of shaking table tests on geogrid reinforced soil walls by El-Emam and Bathurst [37], where amplifications of the wall increased with increase in base acceleration.

\section{Effect of Geocell Configuration}

Effect of geocell configuration on the seismic response of geocell retaining walls was studied through model tests in series Set1 and Set3. In test series Set1, each geocell layer consisted of 4 cells along the length and 5 cells along the width. All these cells were filled with gravel. In test series Set3, each geocell layer consisted of 2 cells along the length and 5 cells along the width. Considering that the geocells along with the gravel fill form the facing of the retaining walls, thickness of the facing is reduced by $50 \%$ in Set3 compared to Set1. Displacements of retaining walls tested at frequencies 1, 2, 3 and $7 \mathrm{~Hz}$, keeping the acceleration amplitude as $0.3 \mathrm{~g}$ are shown in Fig. 10. As observed from the results, maximum displacement observed for geocell wall with Set1 configuration was slightly less than that of Set 3 at all frequencies because of its higher stability due to larger geocell fascia thickness. However, the increase in deformations in case of Set3 

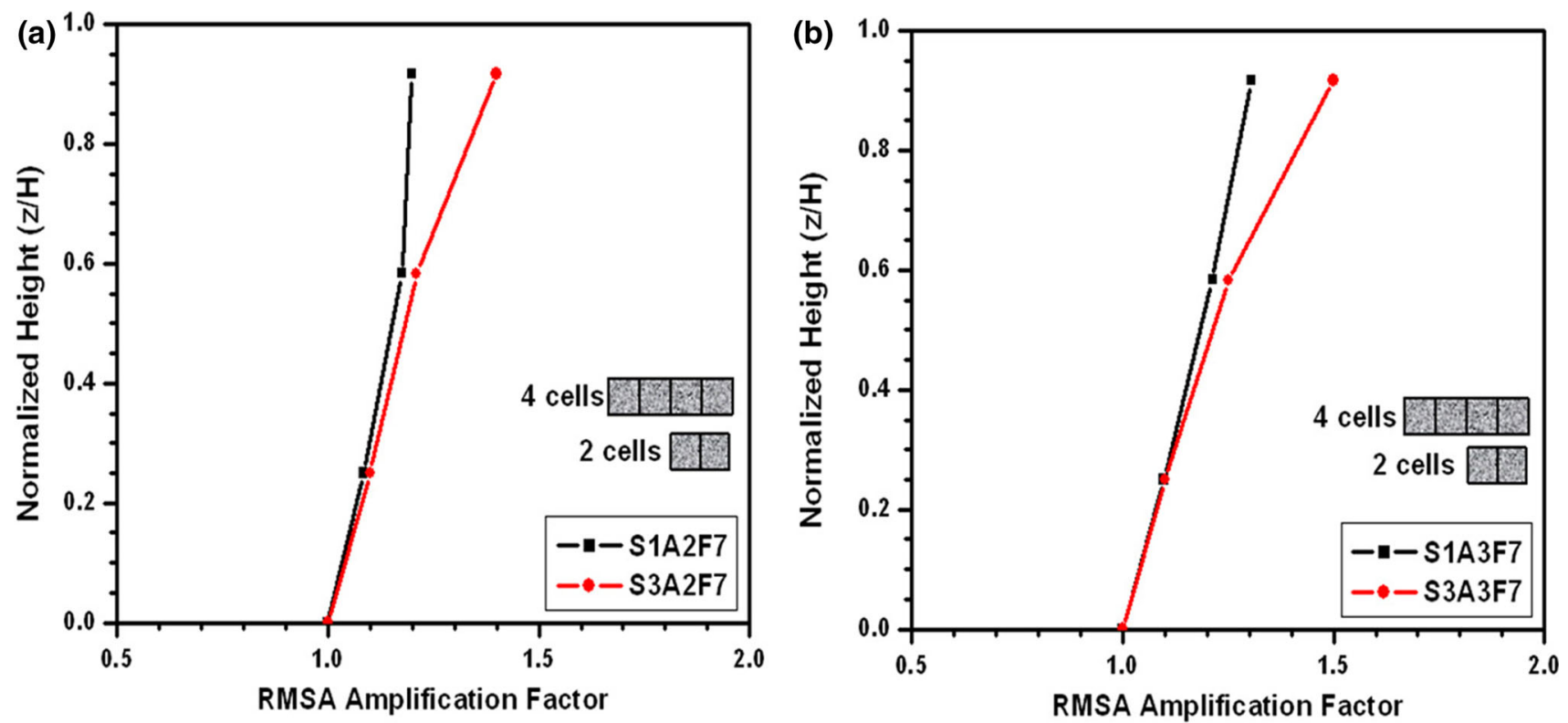

Fig. 11 Effect of geocell configuration on RMSA amplification factors a $1 \mathrm{~Hz}$ b $2 \mathrm{~Hz}$ c $3 \mathrm{~Hz}$ d $7 \mathrm{~Hz}$

configuration is not substantial enough, considering the savings in geocell material, gravel and cost of the wall.

Figure 11 shows the comparison of RMSA amplification factors for Set 1 and Set 3 configurations at $7 \mathrm{~Hz}$ frequency, with acceleration amplitudes of 0.2 and $0.3 \mathrm{~g}$. Accelerations were amplified more in case of Set3 configuration because of its lesser stiffness compared to Set1 configuration, which results in lesser impedance to the seismic wave propagation to the top layers, which in turn results in higher amplification factors. Results from this set of tests clearly indicate that increasing geocell fascia thickness will not result in proportional decrease in deformations and acceleration amplifications. Optimal thickness of the wall facing needs to be worked out based on the design earthquake parameters and allowable deformations and amplifications.

\section{Effect of Fill Material}

Geocells derive their strength and stiffness from the friction generated between the geocell walls and fill material along with the overall confinement effect and interaction between the neighbouring cells. It is very important to select appropriate geocell fill material to derive maximum benefit from the geocells. Krishnaswamy et al. [38], Han et al. [39] and Hegde and Sitharam [40] demonstrated the effect of infill material on the performance of geocells. Though a well-graded angular infill with higher friction angle is the most beneficial choice, many times the choice of infill depends on the availability of materials, costs involved in transportation and the overall cost of the project. Effect of geocell infill material on the seismic performance of walls made using these geocells as fascia was investigated through model tests on geocell walls of configurations Set1 and Set2. Both these sets have four geocells forming the overall fascia thickness. Since the geocells in this study are made using geonets with openings larger than the size of sand particles, it was impossible to use sand in geocells forming the outer layer of the wall fascia. To arrest the flow of sand through the apertures of geocells, the front two geocells of each layer were invariably filled with gravel. In Set1 configuration, the other two cells were also filled with gravel as shown in Fig. 3. In Set2 configuration, two front cells were filled with gravel and the other two cells on the backfill side were filled with backfill sand. Performance of these two configurations are compared in terms of wall deformations and acceleration amplifications.

Figure 12 shows the comparison of wall deformations at 1, 2, 3 and $7 \mathrm{~Hz}$ frequencies and $0.3 \mathrm{~g}$ acceleration.

As observed from the figure, Set2 configuration showed slightly higher deformations compared to Set1 configuration at all frequencies. Since all geocells were filled with grave1 in case of Set1, it has higher stability and stiffness under static as well as dynamic conditions. Fine sand filled in two rear cells forming the fascia in case of Set 2 caused slight increase in deformations. However, this increase is marginal at frequencies up to $2 \mathrm{~Hz}$, the normal range of 

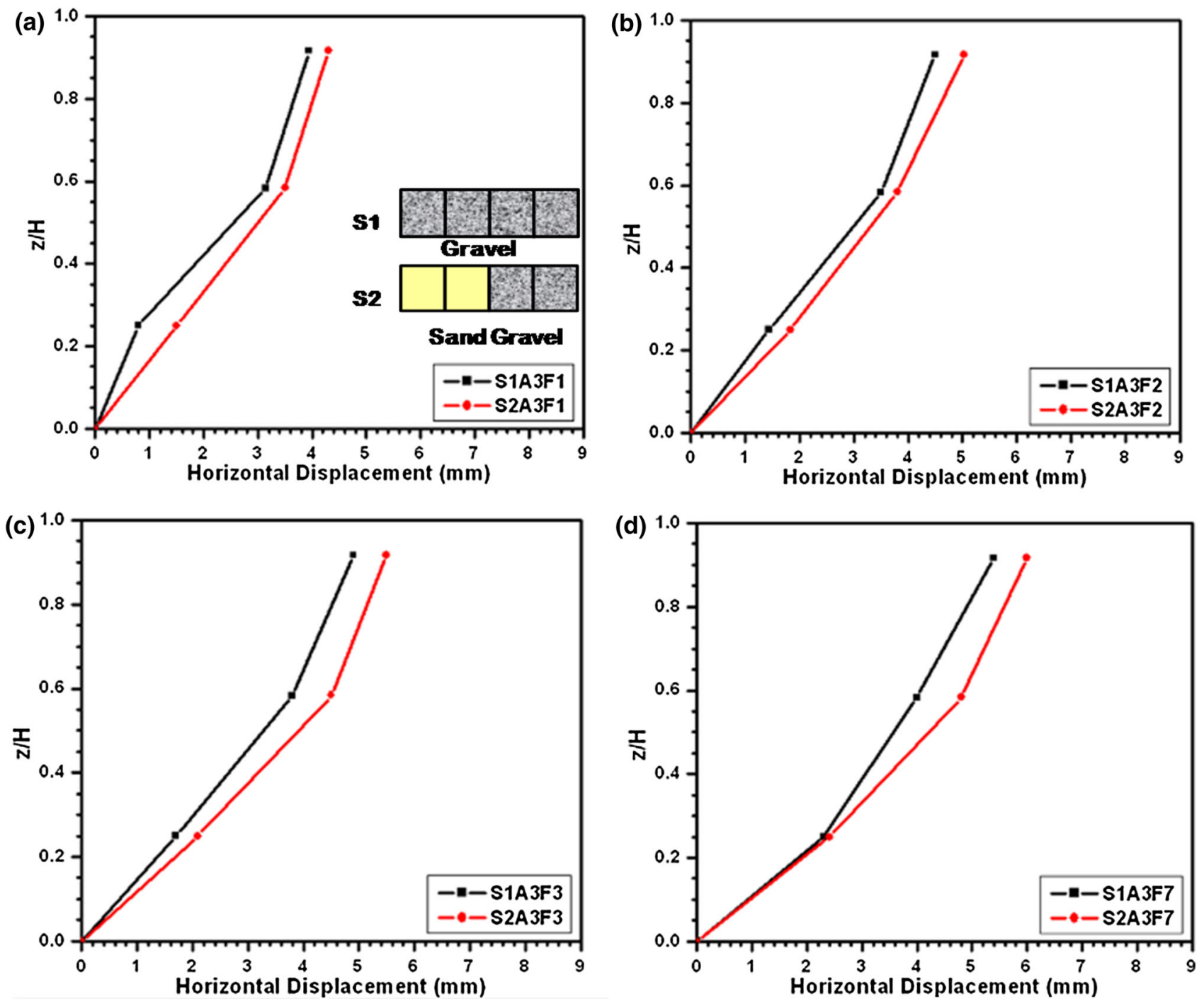

Fig. 12 Effect of geocell infill on wall deformations a $1 \mathrm{~Hz}$ b $2 \mathrm{~Hz}$ c $3 \mathrm{~Hz}$ d $7 \mathrm{~Hz}$

frequencies in seismic events. Comparisons of RMSA amplification factors at $1,2,3$ and $7 \mathrm{~Hz}$ frequencies and $0.3 \mathrm{~g}$ acceleration is shown in Fig. 13. As observed, acceleration amplifications are almost the same for both these configurations at all elevations of the walls at all frequencies. These observations lead to a conclusion that in case of geocells filled with gravel, filling backfill material in few rear cells geocell will not alter the seismic performance of the walls in terms of horizontal deformations of the wall and acceleration amplifications.

\section{Crest Settlements}

Crest settlements were measured in reinforced and unreinforced portions of the backfill at the end of the test at different points. Visual observations showed that when all cells were filled with gravel (Set1 and Set3), quite a bit of backfill sand was flowing into the rear cells because of large void spaces available, causing the formation of small craters at the end of geocell fascia. In case of Set 2 configuration, this flow of fine sand into the rear cells was arrested. However, sand from rear cells entered the front cells filled with gravel, resulting in higher settlements at the junction of sand filled and gravel filled geocells. Measured crest settlements for all three wall configurations are shown in Fig. 14. Crest settlements were more than the horizontal deformations of the wall under seismic excitation. As the applied cyclic shear stress causes vibration and densification of the cohesionless fill materials, crest settles and the settlement is non-uniform only for the cases where the backfill and geocell infill materials are 

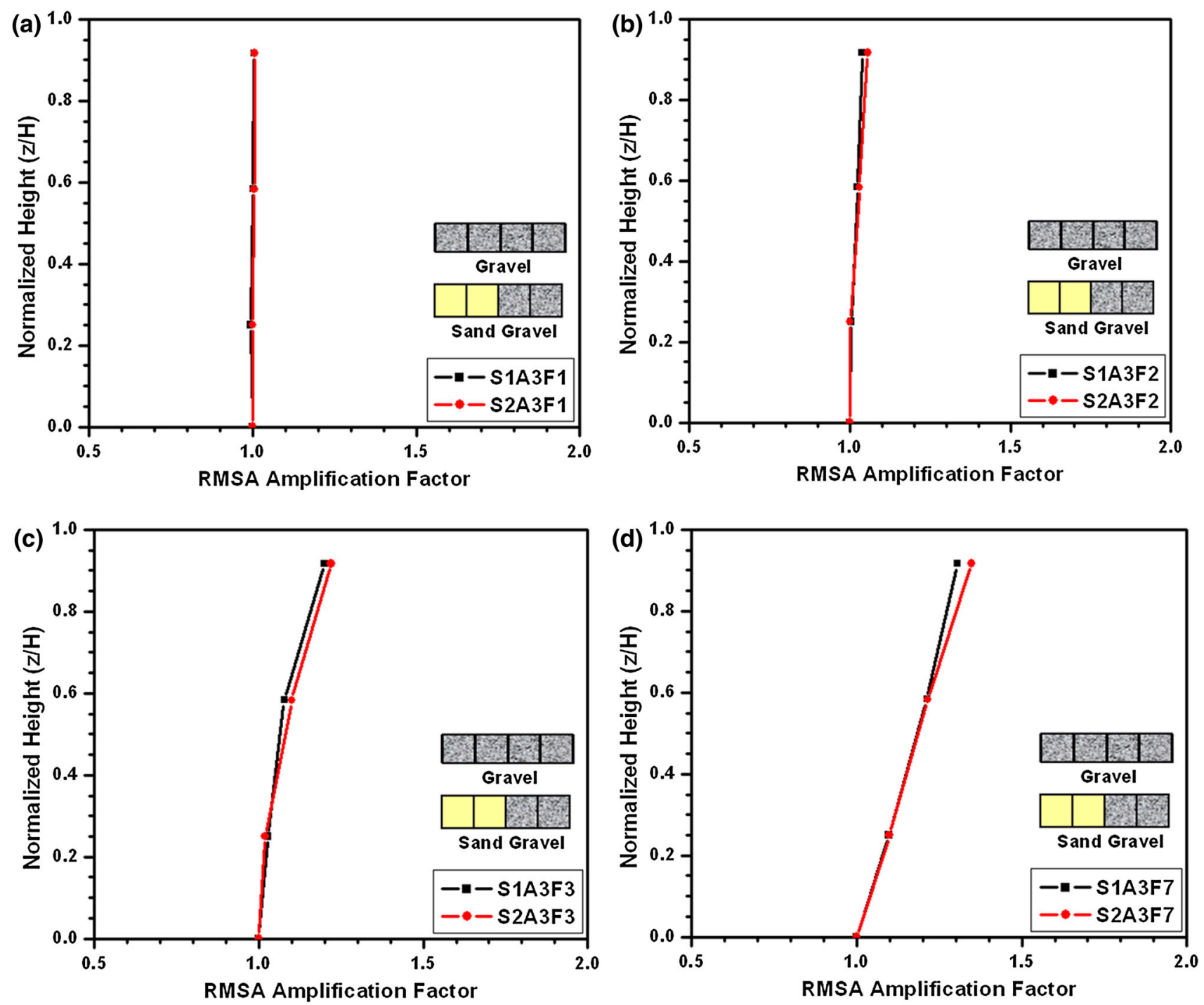

Fig. 13 Effect of geocell infill on RMSA amplification factors a $1 \mathrm{~Hz}$ b $2 \mathrm{~Hz}$ c $3 \mathrm{~Hz}$ d $7 \mathrm{~Hz}$

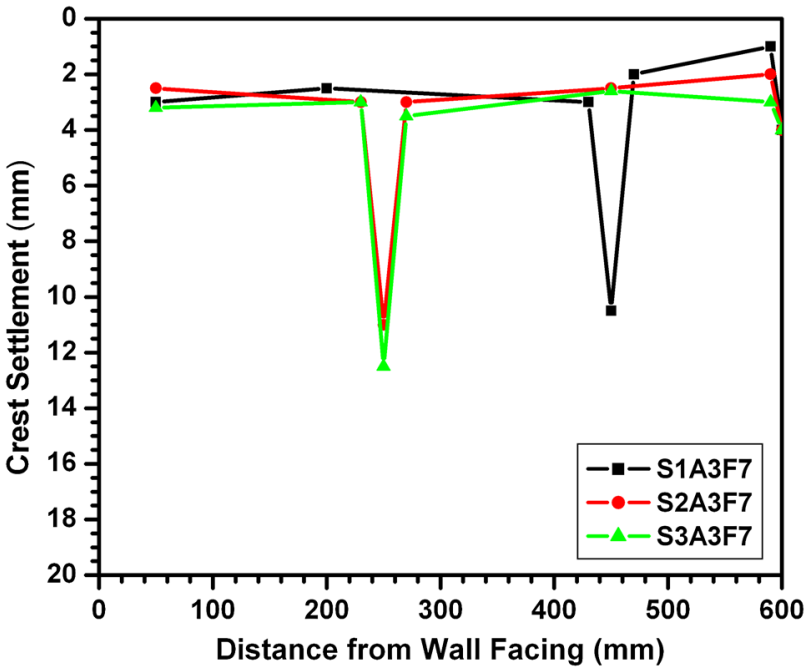

Fig. 14 Variation of crest settlement along the length of the wall for different configurations $(0.3 \mathrm{~g}$ acceleration, $7 \mathrm{~Hz}$ frequency) different. The loss in height of the geocell wall due to densification of fill material can be recovered by filling more material after a seismic event.

\section{Conclusions}

Following major conclusions are drawn from reduced scale shaking table model tests on geocell retaining walls.

1. Frequency of shaking affects the horizontal deformation of the wall and RMSA amplification factors significantly. Displacements and amplifications increase with the increase in frequency of shaking, the effect being more pronounced at lower acceleration amplitudes. 
2. Increase in base acceleration increases the deformations of the geocell retaining walls. Acceleration amplifications are not much affected by the change in base acceleration, especially at lower frequencies.

3. Increasing geocell fascia thickness will not result in proportional decrease in deformations and acceleration amplifications. Optimal thickness of the wall facing needs to be worked out based on the design earthquake parameters and allowable deformations and amplifications.

4. In case of geocells filled with gravel, filling backfill material in few rear cells geocell will not alter the seismic performance of the walls in terms of horizontal deformations of the wall and acceleration amplifications. However, differential settlements of the crest becomes an issue if the fill material inside the geocells is different from the backfill material.

\section{References}

1. Bathurst RJ, Karpurapu R (1993) Large scale triaxial tests on geocell reinforced granular soils. Geotech Test J 16(3):296-303

2. Cancelli A, Rimoldi A, Montanelli F (1993) Index and performance tests for geocells in different applications. Geosynthetic Soil Test Proced, ASTM STP 1190:64-75

3. Krishnaswamy NR, Rajagopal K, Latha GM (1998) Geocell reinforcement for construction of embankments over soft clay foundation. Proceedings of 2nd international conference on ground improvement techniques. Singapore, pp 251-258

4. Rajagopal K, Krishnaswamy NR, Madhavi Latha G (1999) Behaviour of sand confined with single and multiple geocells. Geotext Geomembr 17(3):171-184

5. Latha GM, Rajagopal K, Krishnaswamy NR (2000) Design of geocell supported embankments. Proceedings of international conference geosynthetics Asia, GA2000. Kuala Lumpur, vol 2, pp 97-102

6. Dash SK, Rajagopal K, Krishnaswamy NR (2004) Performance of different geosynthetic reinforcement materials in sand foundations. Geosynth Int 11(1):35-42

7. Latha GM, Murthy VS (2007) Effects of reinforcement form on the behaviour of geosynthetic reinforced sand. Geotext Geomembr 25:23-32

8. Wang YM, Chen YK, Wang CS, Hou ZX (2008) Large direct shear testing of geocell reinforced soil. Adv Transp Geotech 759:764

9. Latha GM, Somwanshi AB (2009) Bearing capacity of square footings on geosynthetic reinforced sand. Geotext Geomembr 27:281-294

10. Tafreshi SNM, Khalaj O, Dawson AR, Masek B (2015) Repeated load response of soil reinforced by two layers of geocell. Procedia Earth Planet Sci 15:99-104

11. Hegde A, Sitharam TG (2015) 3-Dimensional numerical modelling of geocell reinforced sand beds. Geotext Geomembr 43(2):171-181

12. Bathurst RJ, Crowe RE (1992) Recent case histories of flexible geocell retaining Walls in North America. In: Tatsuoka F, Leschinsky D (eds) Proceedings of conference on recent case histories of permanent geosynthetic reinforced soil retaining walls, Tokyo, pp 3-20
13. Racana N, Gourves R, Grediac M (2001) Mechanical behaviour of soil reinforced with geocells. J Geotech Geoenviron Eng 32(3):388-400

14. Chen RH, Chiu YM (2008) Model tests of geocell retaining structures. Geotext Geomembr 26(1):56-70

15. Chen RH, Huang Yu-Wen, Huang Feng-Chi (2013) Confinement effect of geocells on sand samples under triaxial compression. Geotext Geomembr 37:35-44

16. Gomez D (2013) Physical modelling of the effect of partial saturation on the stability of geocell walls. In: Caicedo B, Murillo C, Hoyos L, Esteban J, Colmenares B (eds) Advances in unsaturated soils, Taylor and Francis, London, pp 117122

17. Soudé M, Chevalier B, Grédiac M, Talon A, Gourvès R (2013) Experimental and numerical investigations of the response of geocell reinforced walls to horizontal localized impact. Geotext Geomembr 39:39-50

18. Cai Z, Bathurst RJ (1996) Seismic induced permanent displacement of geosynthetic-reinforced segmental retaining walls. Can Geotech J 33(6):937-955

19. Ling HI, Leshchinsky D, Perry EB (1997) Seismic design and performance of geosynthetic-reinforced soil structures. Geotechnique 47(5):933-952

20. Bathurst RJ, Hatami K (1998) Seismic response analysis of a geosynthetic reinforced soil retaining wall. Geosynth Int 5(1-2):127-166

21. Matsuo O, Yokoyama K, Saito Y (1998) Shaking table tests and analyses of geosynthetic-reinforced soil retaining walls. Geosynth Int 5(1-2):97-126

22. Perez A, Holtz RD (2004) Seismic response of reinforced steep soil slopes: results of a shaking table study. Geotechnical Engineering for Transportation Projects, ASCE Geotechnical Special Publication No. 126:1664-1672

23. Nova-Roessig L, Sitar Nicholas (2006) Centrifuge model studies of the seismic response of reinforced soil slopes. J Geotech Geoenviron Eng 132(3):388-400

24. Nouri H, Fakher A, Jones CJFP (2006) Development of horizontal slice method for seismic stability analysis of reinforced slopes and walls. Geotext Geomembr 24:175-187

25. Won MS, Kim YS (2007) Internal deformation behavior of geosynthetic-reinforced soil walls. Geotext Geomembr 25(1):10-22

26. Krishna AM, Latha GM (2006) Seismic response of wrap-faced reinforced retaining walls. Proceedings of the first European conference on earthquake engineering and seismology, Geneva, Paper No: 749 (on CD)

27. Krishna AM, Latha GM (2007) Seismic response of wrap-faced reinforced soil-retaining wall models using shaking table tests. Geosynth Int 14(6):355-364

28. Latha GM, Krishna AM (2008) Seismic response of reinforced soil retaining walls: influence of backfill relative density. Geotext Geomembr 26:335-349

29. Latha GM, Santhanakumar P (2015) Seismic response of reduced-scale modular block and rigid faced reinforced walls through shaking table tests. Geotext Geomembr 30:1-10

30. Leshchinsky D, Ling HI, Wang JP, Rosen A, Mohri Y (2009) Equivalent seismic coefficient in geocell retention systems. Geotext Geomembr 27(1):9-18

31. Ling HI, Leshchinsky D, Wang JP, Mohri Y, Rosen A (2009) Seismic response of geocell retaining walls: experimental studies. ASCE J Geotechn Geoenviron Eng 135(4):515-524

32. Iai $S$ (1989) Similitude for shaking table tests on soil-structurefluid models in $1 \mathrm{~g}$ gravitational field. Soils Found 29:105-118

33. Lin ML, Wang KL (2006) Seismic slope behavior in a large-scale shaking table model test Engineering. Eng Geol 86:118-133

34. Mirlatifi SA, Fakher A, Ghalandarzadeh A (2007) Seismic study of reinforced earth walls by shaking table model tests. 4th 
International conference on earthquake geotechnical engineering, Paper No: 1253

35. Guler Erol, Enunlu Ali K (2009) Investigation of dynamic behavior of geosynthetic reinforced soil retaining structures under earthquake loads. Bull Earthq Eng 7:737-777

36. Kramer SL (1996) Geotechnical earthquake engineering. Prentice Hall, Upper Saddle River

37. El-Emam MM, Bathurst Richard J (2007) Influence of reinforcement parameters on the seismic response of reduced-scale reinforced soil retaining walls. Geotext Geomembr 25:33-49

38. Krishnaswamy NR, Rajagopal K, Madhavi Latha G (2000) Model tests on geocell supported embankments constructed over soft clay foundation. ASTM Geotech Test J Geomech Abstr 23:45-54

39. Han X, Mera T, Kiyota T, Katagiri T (2014) Shaking table model tests on reinforced soil retaining walls by using newly-developed geocell reinforcements and geogrid reinforcements. Institute of Industrial Science, University of Tokyo, Bulletin of ERS: 47

40. Hegde AM, Sitharam TG (2014) Effect of infill materials on the performance of geocell reinforced soft clay beds. Geomech Geoeng 10(3):163-173 